\title{
A focus on beta cell mass could help prevent type 2 diabetes
}

\begin{tabular}{|c|c|}
\hline $\begin{array}{l}\text { Diabetes is a global health } \\
\text { problem expected to affect } \\
\text { nearly seven percent of the } \\
\text { world's population by } 2035 \text {. } \\
\text { Treatment broadly focuses } \\
\text { on regulating glucose levels, } \\
\text { and an increase in the range } \\
\text { of pharmacological options } \\
\text { means that it is usually } \\
\text { possible to manage the } \\
\text { condition. However, diabetes } \\
\text { cannot be cured. Professor } \\
\text { Yoshifumi Saisho from Keio } \\
\text { University, apapan, advocates } \\
\text { moving the focus away from } \\
\text { glucose levels and towards } \\
\text { protecting pancreatic beta } \\
\text { cell mass - the cells which } \\
\text { produce insulin - to prevent } \\
\text { patients from developing type } \\
2 \text { diabetes and to promote a } \\
\text { healthy lifestyle. }\end{array}$ & $\begin{array}{l}\text { iabetes mellitus is a growing } \\
\text { health problem worldwide, } \\
\text { accounting for over } 10 \% \text { of } \\
\text { global all-cause mortality, and costing } \\
\text { an estimated } \$ 727 \text { billion in healthcare } \\
\text { expenses as of } 2019 \text {. If diabetes is } \\
\text { not properly managed it can lead to } \\
\text { serious damage to the body, including } \\
\text { the heart, kidney, eyes, and nerves, } \\
\text { and type } 2 \text { diabetes can increase the } \\
\text { likelihood of developing cancer and } \\
\text { dementia. Diabetes results when the } \\
\text { level of blood sugar (glucose) in the } \\
\text { body is too high for too long, and the } \\
\text { body is incapable of reducing the levels } \\
\text { naturally. Glucose comes from the food } \\
\text { we eat and is usually absorbed for use } \\
\text { as energy, but absorption is regulated } \\
\text { by insulin. Insulin is produced by beta } \\
\text { cells in the pancreas (production is } \\
\text { triggered by the presence of glucose) } \\
\text { but in people with diabetes either there } \\
\text { is too little insulin produced or the } \\
\text { body tissues don't react properly to the } \\
\text { insulin, and the glucose isn't absorbed. }\end{array}$ \\
\hline
\end{tabular}

Type 1 diabetes

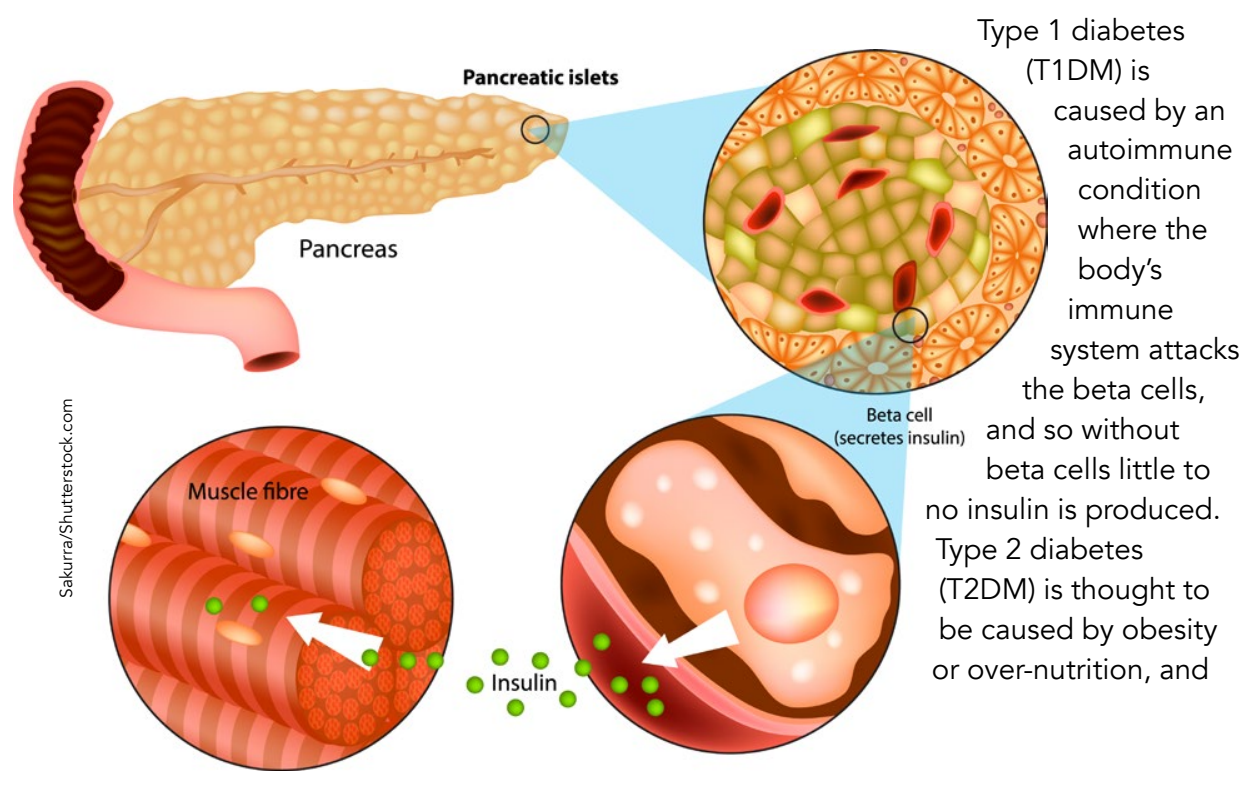

characterised by insulin resistance when the body tissues are less sensitive to insulin and so don't absorb enough glucose. T2DM is diagnosed when threshold, and treatment focuses on maintaining a healthy glucose level (glycaemic control) through medication and lifestyle changes which must be adhered to for the rest of the patient's life. However, Professor Yoshifuni Saisho recommends moving away from this "gluco-centric" approach to T2DM and towards a focus on the insulin-producing beta cells, as a way to improve outcomes for patients with diabetes and to prevent the development of T2DM in those who are at risk.

\section{ETA CELL WORKLOAD}

HYPOTHESIS

By the point at which a patient is have lost around $50 \%$ of their beta cell function (used as a proxy for beta cell mass, which is difficult to measure), either through cell death or cell dysfunction. This is irreversible, and means that insulin production is too low to maintain a healthy blood glucose level.

The process by which beta cell mass might be lost is not clear, but Professor Saisho proposes a "beta cell workload hypothesis", which suggests that overwork could cause dysfunction in beta cells. In an obese patient, beta cells are required to produce large amounts of insulin to trigger the Body tissues may then develop insulin

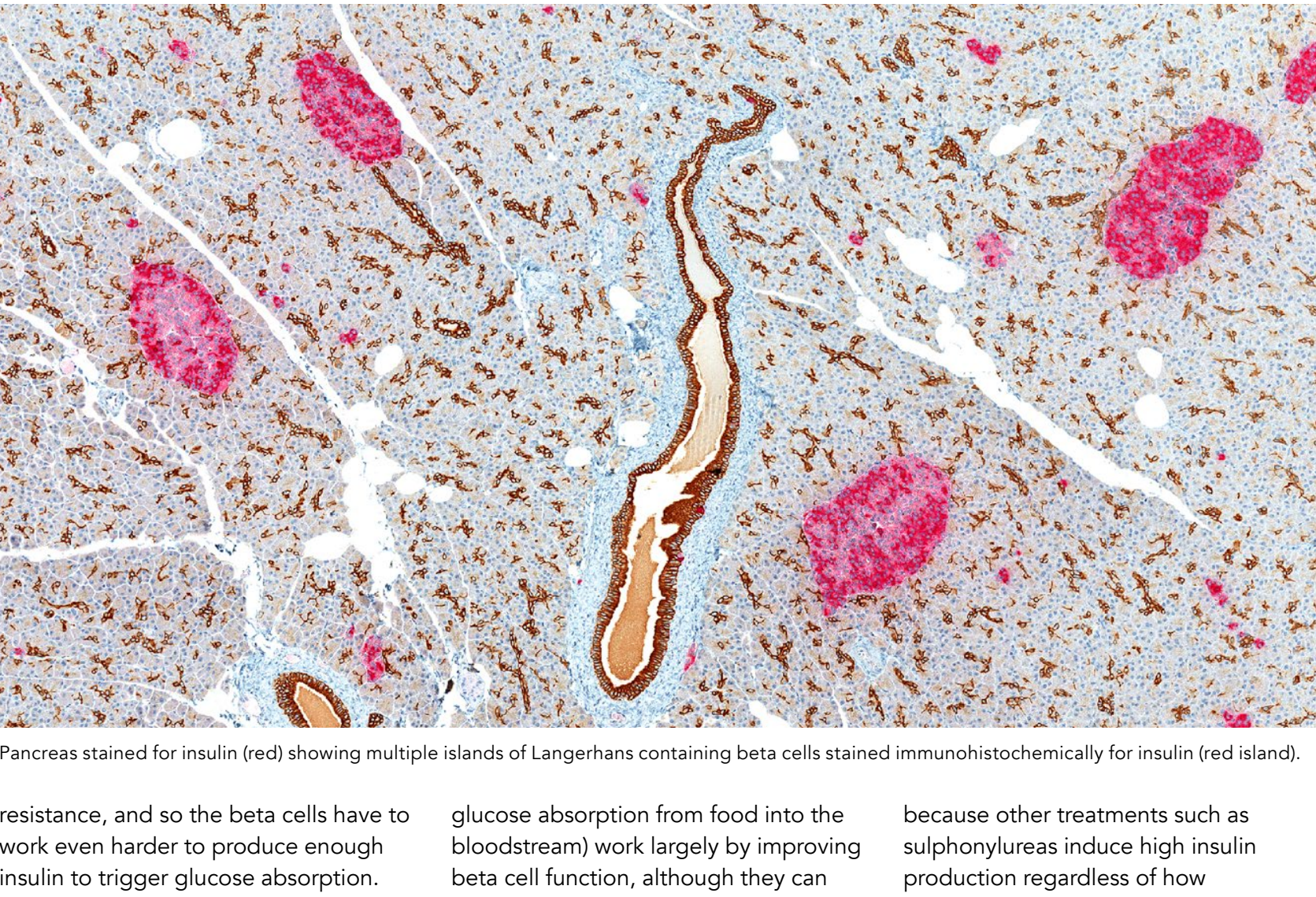

This overwork could cause some beta cells to become impaired or die, which then puts even further stress on the remaining cells. And so as more beta cells die the workload on the remaining cells increases, creating a downwards spiral of beta cell function/ mass. When insulin production drops too far and glucose levels become too high, then the patient is diagnosed weth clabs may also be at risk from the

Professor Saisho suggests that instead of focusing on glucose levels, patients and doctors should focus on beta cell protection.

xicity of hyperglycaemia (high glucose), causing even further After T2DM diagnosis a patient will continue to lose around $5 \%$ of their beta cell function each year, which leads to more difficulty controlling glucose levels and a necessary intensification of treatments.

BETA CELL-CENTRIC APPROACH A beta cell-centric concept of diabetes has already led to the development of new treatments for T2DM. Medications based on the actions of incretin production and lowers the rate of much glucose is present, risking

also keep patients feeling fuller for longer after eating. Incretin-based are lower-risk than other possible preserve beta cell mass in order to maintain glycaemic control.

SGLT2 inhibitors are another group of medications now available to treat T2DM. They work by increasing the amount of glucose that is removed in a patient's urine, and so are thought to reduce the pressure on beta cells. They have been shown to help reduce body weight, and they reduce the risk people with diabetes).

\section{LIFESTYLE CHANGES} However, lifestyle changes are still medications act through a glucose- 


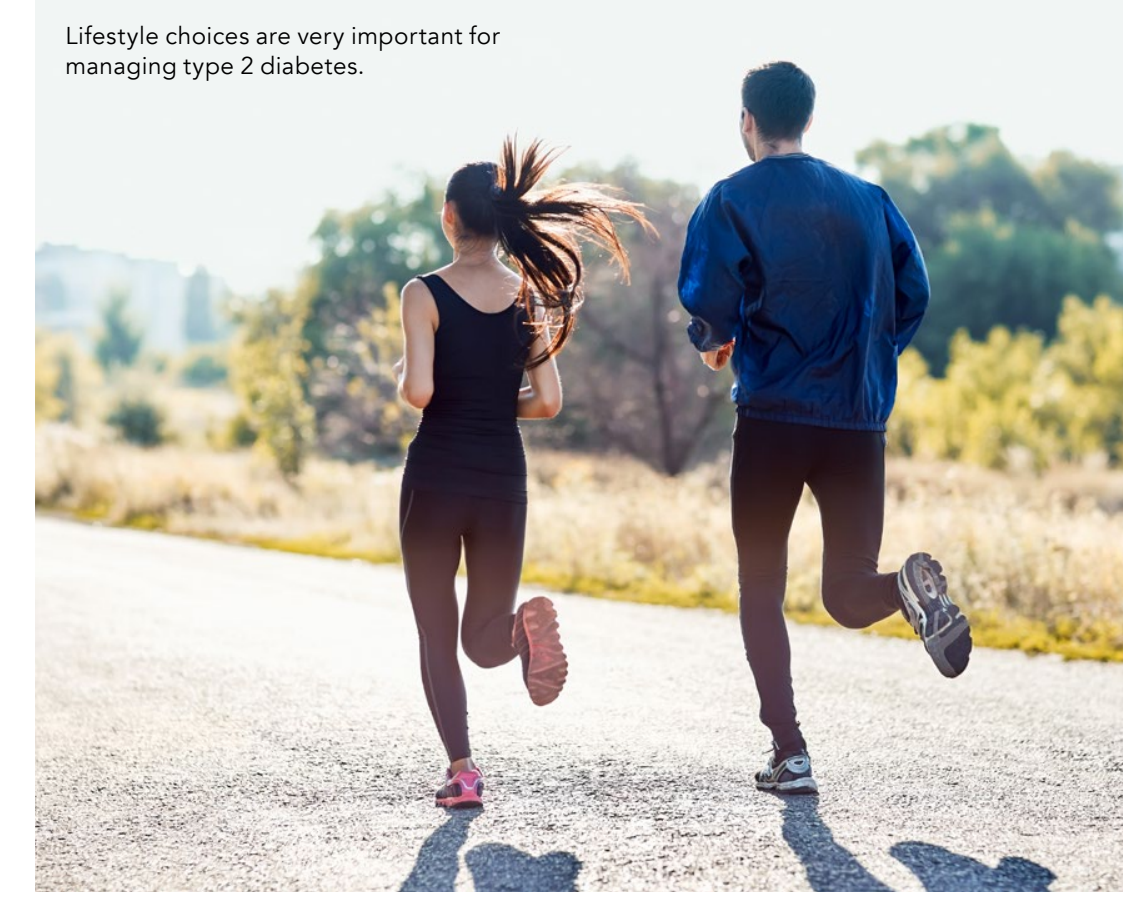

treating T2DM. Weight loss through reduced food intake and regular

exercise reduces beta cell workload and increases the body tissues' sensitivity from the fact that diabetes cannot be cured so people with diabetes must maintain these behaviours over their lifetime, and T2DM is a progressive disorder (in particular due to the continuous loss of beta cell mass) will inevitably worsen over time and patients can feel that their efforts are pointless and stop trits.
to old lifestyle habits.

Professor Saisho suggests that instead of focusing on glucose levels, patients
and doctors should focus on beta cell protection. A beta cell-centric concept of diabetes would help patients to understand that the disease is progressive, but that they can take

action to delay the further dysfunction of beta cells and keep their quality of life better for longer It may also help to put patients and doctors on the same hit to protect beta cells (as opposed to the patient feeling alone th a high risk of developing T2DM, as their condition isn't as serious as diabetes. More effective treatment of those with prediabetes could prevent them developing T2DM, as intervention before the loss of beta cell mass is too great can normalise glucose metabolism. Professor Saisho hopes that by encouraging the use of a beta cell-centric concept of diabetes people will be encouraged to protect this finite resource, and he suggests the use of two terns -karoshi and mottainai- to

\section{KAROSHI AND MOTTAINA} Karoshi is a Japanese term that means "death from overwork", referring to (usually from heart attack or stroke) caused by the stress of a heavy workload. Beta cell karoshi is the same idea - that the beta cells in your pancreas die due to the stress of trying

The idea of beta cell karoshi could motivate people to make better choices to protect their beta cells, lowering their risk of developing diabetes.

in trying to maintain glycaemic control, to manage all the work we place on with the doctor only there to reprimand them with excess eating. Professor Saisho believes that popularising the

\section{PREEMPTIVE ACTION} idea of beta cell karoshi will motiva protect their beta cells, and hopefully lower their risk of developing diabetes. before Tater would be steps taken development of the disease. Patients

Mottainai is the Japanese equivalent of the environmental slogan "reduce, reuse, recycle", except that mottaina also includes the fourth idea of "respect". The term is used to protest people to act in a more sustainable way to save the Earth. Professor Saisho proposes that this can also be applied to beta cell protection to promote lifestyle, and tha we rustainable the pancreas.
- Reduce

- Reuse

- Recycle

Professor saisho proposess that the concepe tof "Mottiaini" can be applied to beta cell protection
Save your pancreas

(beta cells)
- Respect which means that glycaemic contro intensive or immediate treatment those who have been diagnosed with the waste of resources, and encourage lifestyle, and that we reduce beta cell

\section{Behind the Research} Dr Yoshifumi Saisho E: ysaisho@keio.jp T: $+81-3-33531211 \quad$ Fax: +81-3-33592745
W: http://keio-emn.jp/research/group8/

\section{Research Objectives}

Professor Yoshifumi Saisho's research focuses on beta cell dysfunction in type 2 diabetes (T2DM). He mass - the cells which produce insulin - to prevent patients from developing T2DM and to promote healthy lifestyle.

\section{Detail}

Yoshifumi Saisho

Keio University School of Medicine

Department of Internal Medicine

Division of Nephrology, Endocrinology \& Metabolism 35 Shinanomachi Shinjukuku

Tokyo, Japan 1608582

Bio

Yoshifumi Saisho completed his MD in 1998 from Keio University School of Medicine, and his PhD in in the Division of Nephrology, Endocrinology and Metabolism between $2002-2006$. He spent 3 years as a Post-Doctoral Fellow at UCLA before taking position Medicine in 2009

\section{Funding}

Tistry of Education, Culture, Sports, Science and Technology (Grant No.18K08488)

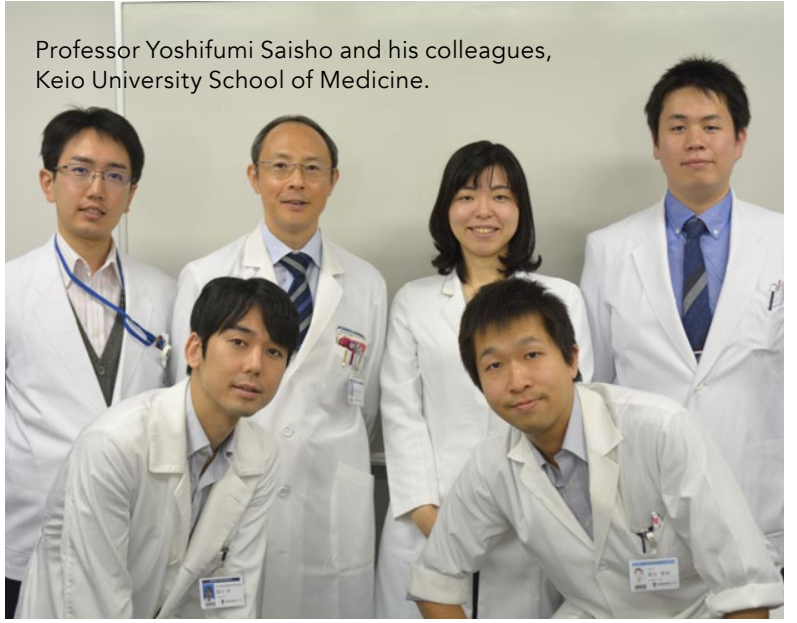
advocates for moving the focus away from glucose 2009 from the same institute. He was a Clinical Fellow

\section{References}

Saisho, Y. (2018). How Can We Develop More Effective Paradigm Shitt from a Glucose-Centric to a Beta CellCentric Concept of Diabetes. EMJ Diabetes 6(1): 46-52.

Saisho, Y. (2019). Changing the Concept of Type 2 Targets 19(2):121-127. DOI:10.2174/187153031866618 Targets 191825

Saisho, Y. (2019). Comprehensive study on human pancreatic $\beta$-cell regulatory mechanism. Impact 2019(2):3840. https://doi.org/10.21820/23987073.2019.2.38

Saisho, Y. (2020). An emerging new concept for the management of type 2 diabetes with a paradigm shift from the glucose-centric to beta cell-centric concept of diabetes - an Asian perspective. Expert Opinion on Pharmacotherapy 21(13):1565-1578. https:///doi.org/10.10 80/14656566.2020.1776262

\section{Personal Response}

Do you think the number of new cases of T2DM could be reduced through popularisation of ideas

Yes. Education and changing mindsets are both use of digital apps to help manage healthy lifestyles will be useful tools to help promote this concept. The development of digital apps based on the concept reduce the number of new cases of T2DM. Strategies for Type 2 Diabetes Mellitus Prevention? A Diabetes: Beta Cell Workload Hypothesis Revisited.

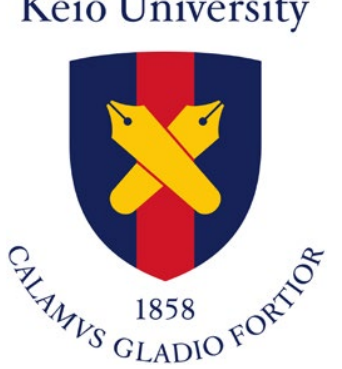

